\title{
Investigation of hand function among children diagnosed with autism spectrum disorder with upper extremity trauma history
}

\author{
Meral Huri, M.D., Sedef Şahin, M.D., Hülya Kayıhan, M.D. \\ Department of Occupational Therapy, Hacettepe University Faculty of Health Sciences, Ankara-Turkey
}

\begin{abstract}
BACKGROUND: The present study was designed to compare hand function in autistic children with history of upper extremity trauma with that of autistic children those who do not have history of trauma.
\end{abstract}

METHODS: The study group included total of 65 children diagnosed with autism spectrum disorder (ASD) and was divided into 2 groups: children with trauma history (Group I) and control group (Group II) (Group I: $n=28$; Group II: $n=37$ ). Hand function was evaluated with 9-Hole Peg Test and Jebsen Hand Function Test. Somatosensory function was evaluated using somatosensory subtests of Sensory Integration and Praxis Test. Results were analyzed with Student's t-test and Mann-Whitney U test using SPSS version 20 software.

RESULTS: Hand function and somatosensory perception test scores were statistically significantly better in children without upper extremity trauma history $(p<0.05)$. When association between hand function tests and upper extremity somatosensory perception tests was taken into account, statistically significant correlations were found between all parameters of hand function tests and Manual Form Perception and Localization of Tactile Stimuli Test results $(p<0.05)$.

CONCLUSION: Autistic children with upper extremity trauma history had poor somatosensory perception and hand function. It is important to raise awareness among emergency service staff and inform them about strong relationship between somatosensory perception, hand function, and upper extremity trauma in children with ASD in order to develop appropriate rehabilitation process and prevent further trauma.

Key words: Autism; hand; tactile perception.

\section{INTRODUCTION}

Hand and upper extremity traumas are one of the most important health problems for children after the age of I year old, and it is one of the most common reasons for visits to emergency services. ${ }^{[1,2]}$ According to results of 2 retrospective studies, the percentage of patients applying to pediatric emergency services for hand injuries in children were $1.7 \%$ and $2 \%$, respectively; $65 \%$ of them were bone injuries, while $33 \%$ of them were soft tissue injuries. ${ }^{[3]}$ The incidence of having a bone injury before 2 years of age was 34/100,000,

Address for correspondence: Meral Huri, M.D.

Hacettepe Üniversitesi Sağlık Bilimleri Fakütesi, Ergoterapi Bölümü, Sihhiye, 06460 Ankara, Turkey

Tel: +90532 - 6555590 E-mail: meralhuri@yahoo.com

Qucik Response Code Ulus Travma Acil Cerrahi Derg

20I6;22(6):559-565
doi: $10.5505 /$ tjtes.20I6.587/2

Copyright 2016

TJTES
$663 / 100,000$ for 10-year-old children and 4/8/100,000 overall. ${ }^{[3,4]}$ Additionally, according to results of a meta-analysis, having a disability makes a child more vulnerable to trauma. It was reported that $33 \%$ of disabled children faced an upper extremity trauma that led them to seek care at pediatric emergency services during their lifetime. ${ }^{[5]}$ Approximately $32 \%$ of these disabled children treated at emergency services were diagnosed with physical disability, while $24 \%$ were diagnosed with neurodevelopmental disorder. ${ }^{[4]}$

Autism spectrum disorder (ASD) is defined as neurodevelopmental disorder characterized by impaired social interaction and communication, both verbal and non-verbal, as well as restricted and repetitive behavior with sensory difficulties. $^{[6]}$ Number of children with ASD is increasing; medical and emergency service staff need to be more aware of commonly seen sensory, motor, and perceptual differences in these children, as they can include self-injury behaviors or lead to trauma while participating in activities of daily living (ADL). ${ }^{[7]}$

For example, 2 studies reported that children with autism 
have self-injury behavior rate ranging from $5 \%$ to $66 \%$, and that childhood trauma occurred during daily activities at rate ranging from $12 \%$ to $53 \% .^{[7,8]}$ lannuzzi et al. suggested that trauma among children with ASD may be related to somatosensory (tactile and proprioceptive) perception and praxis problems (limitations in ideation, problem solving, and motor planning), which can cause stereotypical hand behaviors and clumsiness in daily life. ${ }^{[7]}$ Somatosensory perception of children with ASD has been found to be lower than typically developing peers in various studies. ${ }^{[9,10]}$ There is also strong research supporting idea that hand function in children with ASD is lower than typically developing peers. ${ }^{[1]}$ But researchers are still trying to understand the complex relationship between advanced skills and hand/upper extremity function in children diagnosed with ASD. ${ }^{[10-12]}$

To our knowledge, this is the first study reporting the sensory and functional differences between autistic children with and without upper extremity trauma history. The primary purpose of the study was to compare levels of somatosensory perception and hand function between autistic children with and without upper extremity trauma history.

\section{MATERIALS AND METHODS}

Department of Occupational Therapy at Hacettepe University Faculty of Health Sciences is a referral center for pediatric rehabilitation with interdisciplinary team of occupational therapists and physical therapists. Pediatric Rehabilitation Unit of the department accepts pediatric patients with various diagnoses such as autism spectrum disorders, cerebral palsy, neuromuscular disorders, and learning disorders. The present study is a single-centered retrospective analysis of children who participated in occupational therapy at the Pediatric Rehabilitation Unit between September 2, 2014 and January I, 2016. All data used in this study were collected from database of Pediatric Rehabilitation Unit. Relevant information from patient medical files was recorded on standardized data collection form and subsequently entered into a database. All information in the database was double-checked against data collection forms. Random sample of $10 \%$ of medical files was rechecked and compared with data collection form for any errors. If error rate greater than $5 \%$ was found, study protocol required rechecking another random sample of $40 \%$ of patient files. Any discrepancies found were corrected. Data were de-identified to maintain patient privacy. Individual patient consent was not obtained. The Hacettepe University ethics committee approved the study.

Total of 323 files were evaluated. Children aged between 3 years and 8 years, II months and who had been diagnosed with ASD according to criteria of Diagnostic and Statistical Manual of Mental Disorders (DSM)-5, with intelligence quotient (IQ) score of at least 60 were included. Children with mixed developmental disorders or medical disorders such as additional mental retardation, congenital anomalies/ malformations ( $8 \mathrm{I}$ children), unexpected brain anomalies ( 7 children), disorders with auditory or visual cortex problems ( 19 children), systemic disease such as diabetes or metabolic syndrome ( 3 children), epilepsy ( 2 I children), and chromosome abnormalities such as Fragile $X$ Syndrome ( 3 children) were excluded. Files with missing data were eliminated (33 children). In total, 65 children met the inclusion criteria and were included in the study. Study participants were separated into 2 groups: children with trauma history were placed in Group I ( $n=28$; male: 22; mean age: 6.42 \pm 2 .I years) and children without history of trauma made up Group II $(n=37$; male: 32 ; mean age: $7.13 \pm 1.5$ years).

Demographic information form developed by the authors and used regularly during initial evaluation of children who apply for occupational therapy was used. Form includes details of age, gender, IQ level (obtained from medical records and parental interview), parental information, severity of autism, trauma history, and physical and social development milestones.

Somatosensory subtests of Sensory Integration and Praxis Test (SIPT) were used to evaluate tactile, muscle, and joint perception of the hand and upper extremity, while 9-Hole Peg Test (9-HPT) and Jebsen Hand Function Test were used to assess hand function. These are the gold standard tests for children and they are used worldwide by occupational therapists.

SIPT is a valid and reliable test for assessing sensory integration and praxis skills of children aged between 4 years and 8 years, II months. Certified occupational therapist administers Manual Form Perception, Kinesthesia, Graphesthesia, Finger Identification, and Localization of Tactile Stimuli subtests of SIPT to evaluate somatosensory perception. Manual Form Perception and Localization of Tactile Stimuli subtests specifically test somatosensory perception, while the other tests include assessment of praxis. ${ }^{[13-17]}$

The 9-Hole Peg Test is a brief, standardized, quantitative test of upper extremity function. Both dominant and non-dominant hands are tested twice. Child is seated at a table with a small, shallow container holding 9 pegs and a wooden or plastic block with 9 empty holes. Start command is given, stopwatch is started, and patient picks up the 9 pegs $I$ at a time as quickly as possible using just the hand being tested, puts them in the holes, and, once 9 holes are filled, removes the pegs one at a time, replacing them in the shallow container as quickly as possible. Time required to complete the task is recorded. Two consecutive trials with dominant hand are immediately followed by 2 consecutive trials with nondominant hand. ${ }^{[18,19]}$

Jebsen Hand Function Test evaluates unilateral hand skills and provides an objective assessment of hand function involved in ADL. Test includes a series of 7 subtests performed with 
each hand that represent a wide range of tasks involving upper extremities. Subtests consist of the following: (I) printing a 24-letter, third-grade reading difficulty sentence; $(2)$ turning over $7.6 \times 12.7 \mathrm{~cm}(3 \times 5$ in) cards (simulated page turning); (3) picking up small, common objects (such as coins, paper clips, bottle caps) and placing them in a container; (4) stacking checkers (test of eye-hand coordination); (5) simulated feeding; (6) moving large, empty cans; and (7) moving large, weighted $(0.45 \mathrm{~kg})$ cans. Subtest scores are the number of seconds required to complete each task. ${ }^{[20,21]}$

All statistical analysis was performed using SPSS software, version 20 (SPSS, Inc., Chicago, IL, USA). ${ }^{[22]}$ Descriptive statistics, including proportions, means, medians, standard deviations, and confidence intervals were calculated for demographic characteristics, clinical features, and test results. Student's t-test and Mann-Whitney $U$ test, were used to analyze the data, as appropriate. Statistical significance was defined as $\mathrm{p}<0.05$.

\section{RESULTS}

Total of 65 children with ASD were included in the study. Group I comprised 28 children with mean age of $6.42 \pm 2$. I years; 22 were male and 6 were female. There were 37 children in Group II with mean age of $7.13 \pm 1.5$ years; 32 were male and 5 were female. Severity of ASD according to DSM-
5 in Group I was 25\% ( $n=7)$ severe, $35.7 \%(n=10)$ moderate, and 39.2\% ( $n=11)$ mild; in Group II, $27.2 \%(n=10)$ were classified as severe, $32.4 \%(n=12)$ moderate, and $40 \%(n=15)$ mild. When trauma history was evaluated for Group I, 53.5\% $(n=15)$ were orthopedic injuries caused by fall (bone injuries resulting from fall on stairs, from window or high place, wrist injuries), $35.7 \%(n=10)$ were soft tissue injuries to upper extremity or hand (self-injury, knife cut, burn, bite), and $10.7 \%$ $(n=3)$ were upper extremity injuries caused by total body complex trauma (struck by car as result of pedestrian error, home or school accidents).

Mean age of mother at childbirth in Group I was $25.43 \pm 5.34$ years and $67.8 \%(n=19)$ had graduated from university. Mean age of mother was $33.62 \pm 6.19$ years and $64.8 \%(n=24)$ had graduated from university in Group II. The 2 groups were statistically different according to mother's age and education level $(p<0.05)$.

Table I illustrates comparison of average scores of Group I and Group II on Manual Form Perception, Kinesthesia, Finger Identification, Graphesthesia, and Localization of Tactile Stimuli subtests. Results indicated that autistic children with trauma history had significantly lower scores on all somatosensory perception subtests than autistic children without trauma history $(p<0.05)$.

Table I. Somatosensoriel perception tests scores for Group I and Group II

\begin{tabular}{|c|c|c|c|c|}
\hline & $\begin{array}{l}\text { Group I } \\
(n=28)\end{array}$ & $\begin{array}{c}\text { Group II } \\
(n=37)\end{array}$ & $\mathbf{T}$ & $\mathbf{p}$ \\
\hline Manual Form Perception & -2.76 & -.1 .82 & -2.13 & $<0.001$ \\
\hline Kinesthesia & -3.00 & -2.75 & -1.63 & $<0.001$ \\
\hline Graphesthesia & -2.80 & -2.13 & -3.54 & $<0.001$ \\
\hline Finger Identification & -2.86 & -1.91 & -3.41 & $<0.001$ \\
\hline Localization of Tactile Stimuli & -2.02 & -1.85 & -2.43 & $<0.001$ \\
\hline
\end{tabular}

Table 2. Scores of 9-Hole Peg Test for Group I and Group II

\begin{tabular}{|c|c|c|c|c|}
\hline & $\begin{array}{l}\text { Group I } \\
(n=28)\end{array}$ & $\begin{array}{c}\text { Group II } \\
(n=37)\end{array}$ & $\mathbf{T}$ & $\mathbf{p}$ \\
\hline & Mean $\pm S D$ & Mean $\pm S D$ & & \\
\hline \multicolumn{5}{|c|}{ 9-Hole Peg Test (right-hand, s) } \\
\hline Insert & $74 \pm 37.43$ & $57.34 \pm 21.32$ & -8.34 & $<0.001$ \\
\hline Extract & $41.34 \pm 11.2$ & $29.43 \pm 11.23$ & -6.31 & $<0.001$ \\
\hline \multicolumn{5}{|c|}{ 9-Hole Peg Test (left-hand, s) } \\
\hline Insert & $88.43 \pm 43.45$ & $61.43 \pm 32.61$ & -7.45 & $<0.001$ \\
\hline Extract & $53.2 I \pm 6.62$ & $18.45 \pm 8.5$ & -7.12 & $<0.001$ \\
\hline
\end{tabular}

SD: Standard deviation. 
Table 2 demonstrates comparison of average speed of Group I and Group II on 9-Hole Peg Test. According to the results, slower speed of autistic children with trauma history was statistically significant $(p<0.05)$.

Comparison of average speed in each performance of Group I and Group II for Jebsen Hand Function Test can be seen in Table 3. Performance of autistic children with trauma history was statistically significantly slower than that of the autistic children without trauma history $(p<0.05)$.

Relationships between somatosensory perception subtests and hand function tests are provided in Table 4. Negative correlations between scores on Manual Form Perception, Localization of Tactile Stimuli subtests, all subtests of 9-Hole Peg Test, and Jebsen Hand Function Test were found $(p<0.05)$.

\section{DISCUSSION}

There are variety of upper extremity traumas that children can face during childhood. Although their recovery is better than that of adults, trauma during childhood can cause longterm severe injuries. ${ }^{[-4]}$ If they do not reach motor, sensory, or cognitive developmental milestones, children with disabilities can have difficulty adapting to their environment, and this makes them more vulnerable to trauma. ${ }^{\left[{ }^{[}\right]}$
Especially for children with ASD, developmental delays in sensory and motor performance can lead to childhood trauma such as upper extremity self-injury behavior or clumsiness due to dyspraxia (motor planning problems). ${ }^{[7]}$ The aim of the present study was to compare levels of somatosensory perception and hand function in autistic children with and without history of upper extremity trauma.

Studies have reported that trauma in childhood is seen more often in boys than girls in the 10- to 12-year-old age group, and that incidence of trauma is higher among 13- to 14-yearolds with physical disabilities while it is high in 6- to 8-year-old children with neurodevelopmental disorders such as ASD. ${ }^{[1-5]}$ Trauma history data of children in the present study reflected similar age and gender characteristics. ${ }^{[1-5]}$ It is thought that the incidence of ASD is 4 times higher in boys than in girls, but when seen in girls, the severity of autism is often greater. ${ }^{[6-8]}$ As a result, girls are often less independent in performing daily living activities, and therefore they may be more protected from trauma due to greater role of caregiver. Boys may be more vulnerable to trauma and represent the majority of cases despite less severe diagnosis.

Some studies have also reported that children of younger mothers with lower education level suffer greater incidence

Table 3. Scores of Jebsen Hand Function Test for Group I and Group II

\begin{tabular}{|c|c|c|c|c|}
\hline & $\begin{array}{l}\text { Group I } \\
(n=28)\end{array}$ & $\begin{array}{c}\text { Group II } \\
(n=37)\end{array}$ & $\mathbf{T}$ & $\mathbf{p}$ \\
\hline & Mean \pm SD & Mean \pm SD & & \\
\hline Printing & $264.64 \pm 231.94$ & $125.43 \pm 42.54$ & -3.16 & $<0.001$ \\
\hline \multicolumn{5}{|c|}{ Turning over (s) } \\
\hline Right & $11.55 \pm 3.23$ & $9.76 \pm 3.21$ & -3.85 & $<0.001$ \\
\hline Left & $11.43 \pm 2.54$ & $9.12 \pm 2.32$ & -6.73 & $<0.001$ \\
\hline \multicolumn{5}{|c|}{ Picking up objects (s) } \\
\hline Right & $8.77 \pm 3.45$ & $6.81 \pm 3.13$ & -5.14 & $<0.001$ \\
\hline Left & $9.12 \pm 2.78$ & $8.43 \pm 2.65$ & -5.32 & $<0.001$ \\
\hline \multicolumn{5}{|c|}{ Stacking checkers (s) } \\
\hline Right & $12.34 \pm 4.32$ & $5.62 \pm 3.19$ & -4.73 & $<0.001$ \\
\hline Left & $|2.42 \pm 4.5|$ & $7.52 \pm 1.94$ & -3.76 & $<0.001$ \\
\hline \multicolumn{5}{|c|}{ Simulated feeding (s) } \\
\hline Right & $9.54 \pm 1.23$ & $7.73 \pm 1.62$ & -4.82 & $<0.001$ \\
\hline Left & $9.39 \pm 2.74$ & $7.63 \pm 2.71$ & -4.12 & $<0.001$ \\
\hline \multicolumn{5}{|c|}{ Moving large empty can (s) } \\
\hline Right & $13.54 \pm 3.26$ & $7.4 I \pm 2.64$ & -4.23 & $<0.001$ \\
\hline Left & $|2.35 \pm 4.3|$ & $9.52 \pm 1.43$ & -4.63 & $<0.001$ \\
\hline \multicolumn{5}{|c|}{ Moving large weighted can (s) } \\
\hline Right & $14.32 \pm 3.26$ & $8.63 \pm 2.84$ & -5.49 & $<0.001$ \\
\hline Left & $16.53 \pm 4.37$ & $9.4 I \pm 2.23$ & -5.71 & $<0.001$ \\
\hline
\end{tabular}

SD: Standard deviation. 
Table 4. Relationships between Finger Identification and Localization of Tactile Stimuli tests and hand function tests (9-Hole Peg Test and Jebsen Hand Function Test) scores for Group I and Group II

\begin{tabular}{|c|c|c|c|c|}
\hline & \multicolumn{2}{|c|}{ Manual Form Perception } & \multicolumn{2}{|c|}{ Localization of Tactile Stimuli } \\
\hline & $\begin{array}{c}\text { Group I } \\
r(p)\end{array}$ & $\begin{array}{c}\text { Group II } \\
r(p)\end{array}$ & $\begin{array}{c}\text { Group I } \\
r(p)\end{array}$ & $\begin{array}{c}\text { Group II } \\
\text { r (p) }\end{array}$ \\
\hline \multicolumn{5}{|c|}{ 9-Hole Peg Test (total s left and right hand) } \\
\hline Insert & $-0.812(<0.00 \mathrm{I})$ & $-0.623(<0.001)$ & $-0.872(<0.00 \mathrm{I})$ & $-0.673(<0.001)$ \\
\hline Extract & $-0.853(<0.001)$ & $-0.639(<0.001)$ & $-0.874(<0.001)$ & $-0.629(<0.001)$ \\
\hline \multicolumn{5}{|l|}{ Jebsen Hand Function Test } \\
\hline Printing & $-0.7 \mathrm{II}(<0.00 \mathrm{I})$ & $-0.583(<0.00 \mathrm{I})$ & $-0.784(<0.00 \mathrm{I})$ & $-0.591(<0.001)$ \\
\hline Turning over & $-0.817(<0.001)$ & $-0.694(<0.001)$ & $-0.749(<0.001)$ & $-0.632(<0.00 \mathrm{I})$ \\
\hline Picking up objects & $-0.883(<0.001)$ & $0.616(<0.001)$ & $-0.829(<0.001)$ & $-0.548(<0.00 \mathrm{I})$ \\
\hline Stacking checkers & $-0.780(<0.001)$ & $-0.62 I(<0.001)$ & $-0.772(<0.00 \mathrm{I})$ & $-0.63 \mathrm{I}(<0.00 \mathrm{I})$ \\
\hline Simulated feeding & $-0.832(<0.001)$ & $-0.7 \mathrm{II}(<0.00 \mathrm{I})$ & $-0.799(<0.001)$ & $-0.597(<0.001)$ \\
\hline Moving large empty can & $-0.769(<0.001)$ & $-0.597(<0.001)$ & $-0.758(<0.001)$ & $-0.51 \mathrm{I}(<0.00 \mathrm{I})$ \\
\hline Moving large weighted can & $-0.849(<0.001)$ & $-0.623(<0.001)$ & $-0.793(<0.00 \mathrm{I})$ & $-0.526(<0.001)$ \\
\hline
\end{tabular}

$r=$ Spearman correlation coefficient.

of trauma than children with older, more educated mothers. ${ }^{[1-5]}$ In the present study, consistent with the literature, mother's age and education level were lower in cases of children with trauma history than the children without trauma history. It is thought that age and education level of the mother are important to prevention of trauma in children with ASD.

There is good evidence that hand function of typically developing children is better than that of children with disabilities. [II] Children with ASD may have different levels of fine motor skills. ${ }^{[1,12]}$ About $10 \%$ of the children with ASD have a similar level of fine motor skills to each other, but there is a big gap between level of hand function in typically developing children with and without trauma history, and furthermore an even greater gap exists in hand function among autistic children with trauma history. ${ }^{[9,11]}$

The literature supports theory that children with ASD may have somatosensory perception problems. ${ }^{[14,23-26]}$ Consistent with the literature, results of the present study indicated that children with ASD have poor somatosensory scores compared with norms of their typically developing peers. ${ }^{[23-26]}$ However, the literature is still limited regarding somatosensory perception of children with history of trauma. ${ }^{[7,8]}$ As this study is the first study in this area, it provides some evidence that autistic children without trauma history had higher scores on all somatosensory subtests of SIPT, suggesting that children with ASD and trauma history have weaker somatosensory perception.

Physical and social environment have a great impact on sensory and motor development of children. ${ }^{[23,24]}$ Differences in motor and sensory development of children with ASD may affect ability to reach developmental milestones. ${ }^{[23-26]}$ This developmental delay may lead to difficulties carrying out daily living activities. ${ }^{[17,18]}$ Therefore, Jebsen Hand Function Test was used to assess hand function while performing daily living activities, as well as 9-Hole Peg Test, which assesses speed of hand function. According to the literature, endurance and speed in use of upper extremity and hand affect quality life of children with ASD. ${ }^{[20,21]}$ Studies have shown that sensory and motor development differences may cause motor planning difficulty during daily living activities, affecting quality of life of children with ASD from early stage of life..$^{[1-18,23-26]}$ The present study indicated that autistic children without history of trauma had better scores in 9-Hole Peg Test and Jebsen Hand Function Test. It has been determined that autistic children with trauma history had greater limitation in fine motor skills. $\left[{ }^{11,20]}\right.$ It is thought that somatosensory perception problems may increase rate of trauma experience during childhood, and that this may be related to decreased scores for hand function and speed tests.

There are study results demonstrating lower scores on 9-Hole Peg Test and Jebsen Hand Functions Test for children with ASD compared with typically developing peers, but there is not yet sufficient evidence on hand function among children with trauma history. ${ }^{[1,20]}$ Our study revealed that hand function of autistic children with trauma history was slower and poor in comparison with those who did not have trauma history.

Briefly, our study results indicated that somatosensory perception and hand function of autistic children without trauma history was better than those of autistic children with trauma history. Autistic children with history of trauma may 
have somatosensory perception problem that complicates or obstructs achieving greater proficiency level in performance of daily living activities, which may also expose these children to greater risk of further trauma.

The present study demonstrated relationship between somatosensory perception tests and subtests of hand function. Results of Manual Form Perception Test and Localization of Tactile Stimuli Tests correlated with those of the subtests of hand functions in the present study, which is consistent with the literature. ${ }^{[9,10]}$ This result indicates that those tests can not only be used to identify problems and successes in hand manipulation skills of children with ASD, but may provide valuable insight with regard to possible upper extremity trauma. In summary, our study results are initial evidence that children with ASD who have difficulty with Manual Form Perception Test and Localization of Tactile Stimuli Test are more likely to have experienced upper extremity trauma.

All of the tests used in the present study are standardized and can be used to assess children with ASD. It is generally thought that 9-Hole Peg Test is easy and suitable for younger children with ASD. Writing and page-turning subtests of Jebsen Hand Function Test offer advantages for assessment of hand function of school-age children with autism. Eating subtest of Jebsen Hand Faction Test can give indication about hand function while performing daily living activities. Somatosensory perception and hand function of autistic children with trauma were very poor, which increases risk of trauma occurring in daily life. Early occupational therapy interventions to increase somatosensory perception and hand function may help to prevent trauma in autistic children.

\section{Conclusion}

It is crucial to understand upper extremity function in children with ASD as it may affect the child's ability to perform daily living activities. It may be explained by the complex relationships between hand perception and function. Male children with ASD with lower mother education level experienced upper extremity trauma more often than female children with ASD with higher mother education level in the present study. Improving mother's level of awareness about limitations of upper extremity function, perception, and the kinds of traumas that children with ASD can face is very important. Caregivers of children with mild and moderate autistic severity must observe the child while participating in daily living activities to prevent possible upper extremity trauma. Lack of upper extremity perception and function can lead to upper extremity trauma, but can also inform with regard to rehabilitation needs of the children. It is also important to inform and raise awareness of emergency service staff about complex relationships between upper extremity perception, function, and trauma history among children with ASD.

This study will provide basic knowledge for future interdisci- plinary teamwork with rehabilitation therapists and emergency service staff for children diagnosed with ASD and may help the children in this population to be evaluated and treated for somatosensory perception problems earlier and prevent further trauma.

\section{Conflict of interest: None declared.}

\section{REFERENCES}

1. Jiménez-Escobar I, Weingerz-Mehl S, Castillo-Macedo E, JiménezGutiérrez C, Gutiérrez-Castrellón P. Characterization of adolescents and reason for the visit when attending the pediatric emergency department of the General Hospital Dr. Manuel Gea González. [Article in Spanish] Gac Med Mex 2016;152:30-5. [Abstract]

2. Gornitzky AL, Milby AH, Gunderson MA, Chang B, Carrigan RB. Referral Patterns of Emergent Pediatric Hand Injury Transfers to a Tertiary Care Center. Orthopedics 2016;39:333-9. Crossref

3. Valencia J, Leyva F, Gomez-Bajo GJ. Pediatric hand trauma. Clin Orthop Relat Res 2005;(432):77-86. Crossref

4. Duman A, Kapçı M, Bacakoğlu G, Akpınar O, Türkdoğan KA, Karabacak M. Evaluation of trauma patients in emergency department. Medical Journal of Suleyman Demirel University 2014;21:2.

5. Hoxter S. The significance of trauma in the difficulties encountered by physically disabled children. Journal of Child Psychotherapy 1986;12:87-102. Crossref

6. Lauritsen MB. Autism spectrum disorders. Eur Child Adolesc Psychiatry 2013;22:7-42. Crossref

7. Iannuzzi DA, Cheng ER, Broder-Fingert S, Bauman ML. Brief report: Emergency department utilization by individuals with autism. J Autism Dev Disord 2015;45:1096-102. Crossref

8. Kalb LG, Stuart EA, Freedman B, Zablotsky B, Vasa R. Psychiatric-related emergency department visits among children with an autism spectrum disorder. Pediatr Emerg Care 2012;28:1269-76. Crossref

9. Huri M, Mehr BK, Altuntaş O, Kayihan H. Yaygın gelişimsel bozukluğu olan ve normal gelişim gösteren çocukların taktil tercihlerinin karşlaştırılması. Ergoterapi ve Rehabilitasyon Dergisi 2014;2:21-8.

10. Azouz HG, Khalil M, El Ghani HMA, Hamed HM. Somatosensory evoked potentials in children with autism. Alexandria Med J 2014;50:99105. Crossref

11. Provost B, Heimerl S, Lopez BR. Levels of gross and fine motor development in young children with autism spectrum disorder. Phys Occup Ther Pediatr 2007;27:21-36. Crossref

12. Lloyd M, MacDonald M, Lord C. Motor skills of toddlers with autism spectrum disorders. Autism 2013;17:133-46. Crossref

13. Lai JS, Fisher AG, Magalhães LC, Bundy AC. Construct validity of the sensory integration and praxis tests. OTJR 1996;16:75-97. Crossref

14. Roley SS, Mailloux Z, Parham LD, Schaaf RC, Lane CJ, Cermak S. Sensory integration and praxis patterns in children with autism. Am J Occup Ther 2015;69:6901220010.

15. Bodison SC. Developmental Dyspraxia and the Play Skills of Children With Autism. Am J Occup Ther 2015;69:6905185060. Crossref

16. Oswald D. Sensory differences in autism. Research Reports 2013.

17. Stackhouse TM, Kuhaneck HM, Watling R. Motor differences in the autism spectrum disorders. Autism: A comprehensive occupational therapy approach 2010:163-200.

18. Wang YC, Magasi SR, Bohannon RW, Reuben DB, McCreath HE, Bubela DJ, et al. Assessing dexterity function: a comparison of two alter- 
natives for the NIH Toolbox. J Hand Ther 2011;24:313-21. Crossref

19. Wang YC, Bohannon RW, Kapellusch J, Garg A, Gershon RC. Dexterity as measured with the 9-Hole Peg Test (9-HPT) across the age span. J Hand Ther 2015;28:53-9; quiz 60. Crossref

20. Carr K, McKeen P, Daabous J, Azar N, Horton S, Sutherland C. Reliability of four subtests of the jebsen test of hand function among adults with autism and an intellectual disability. Journal of Developmental Disabilities 2015;21:1.

21. Harte D, Curran D, Hamill P, Porter-Armstrong A, Wilson L. Using a template to improve the accuracy and efficiency of the Jebsen-Taylor Hand Function Test: A comparative study. Hand Ther 2014;19:11-6.

22. Pallant, J. SPSS survival manual. McGraw-Hill Education (UK) 2013.
23. Case-Smith J, Bryan T. The effects of occupational therapy with sensory integration emphasis on preschool-age children with autism. Am J Occup Ther 1999;53:489-97. Crossref

24. Pfeiffer BA, Koenig K, Kinnealey M, Sheppard M, Henderson L. Effectiveness of sensory integration interventions in children with autism spectrum disorders: a pilot study. Am J Occup Ther 2011;65:76-85.

25. Schaaf RC, Benevides TW, Kelly D, Mailloux-Maggio Z. Occupational therapy and sensory integration for children with autism: a feasibility, safety, acceptability and fidelity study. Autism 2012;16:321-7. Crossref

26. Schaaf RC, Lane AE. Toward a Best-Practice Protocol for Assessment of Sensory Features in ASD. J Autism Dev Disord 2015;45:1380-95.

\section{ORIJIINAL ÇALIŞMA - ÖZET}

\section{Üst ekstremite travma öyküsü olan otizm spektrum bozukluğu tanılı çocuklarda el fonksiyonlarının değerlendirilmesi \\ Dr. Meral Huri, Dr. Sedef Şahin, Dr. Hülya Kayıhan}

Hacettepe Üniversitesi, Sağlık Bilimleri Fakültesi, Ergoterapi Bölümü, Ankara

AMAÇ: Çalışmamız üst ekstremite travma öyküsü olan ve olmayan otizmli çocukların el fonksiyonlarını karşılaştırmak amacı ile planlandı.

GEREÇ VE YÖNTEM: Çalışmaya otizm spektrum bozukluğu tanısı ile takip edilen toplam 65 (Grup I, n=28; Group II, n=37) çocuk dahil edildi. Çocukların el fonksiyonları 9-Delikli Peg Testi ve Jebsen El Fonksiyon Testi ile değerlendirildi. Üst ekstremite ve elin somatoduyusal algısı Duyusal İşlemleme ve Praksis Testi'nin somatoduyusal algı alt testleri ile değerlendirildi. Sonuçlar Student t-testi and Mann-Whitney U-Testi ile SPSS 20 bilgisayar programı ile karşılaştıııldı.

BULGULAR: Her iki el fonksiyon testine ait sonuçlar travma geçmişi olmayan çocuklar lehine farklı bulundu $(\mathrm{p}<0.05)$. Üst ekstremite somatosensoriyel algı ile el fonksiyon testleri arasındaki ilişki incelendiğinde, çocukların 9-Delikli Peg Testi ve Jebson El Fonsiyonları Test puanları ile Manuel Obje Algısı ve Taktil Uyaranın Lokalizasyonu test puanları arasında istatistiksel olarak anlamlı ilişkiler bulundu $(\mathrm{p}<0.05)$.

TARTIŞMA: Travma öyküsü olan otizm spektrum bozukluğu tanılı çocuklar zayıf somatoduyusal algı ve el fonksiyonlarına sahiptirler. Acil servislerde çalışan profesyonellerin somatoduyusal algı, el fonsiyonları ve üst ektremite travma öyküsü arasındaki kuvvetli ilişki konusunda bilgilendirilip, farkındalıklarının artıııımasınının; bu popülasyondaki çocukların rehabilitasyon süreçleri için önemli olduğu düşünülmektedir. Anahtar sözcükler: Dokunma duyusu; el; otizm.

Ulus Travma Acil Cerrahi Derg 2016;22(6):559-565 doi: 10.5505/tjtes.2016.587/2 